\title{
Incorporating Climate Change Adaptation into Sustainable Development
}

CONTENTS

I. Introduction

1. Research background

2. Research purpose

II. Analytical framework

1. Conceptual setting

2. Methodology

III. Recent trend of climate change adaptation among global donors

1. Mitigation relatively mainstreamed in terms of ODA volume

2. Unbalanced portfolio of climate change adaptation

IV. Current status of climate change adaptation of KOICA

1. Strategic efforts in responding climate change

2. Progress in climate change adaptation at project-level

V. Implications on advancing climate change adaptation for KOICA : Lessons from other donors

1. Strategically syncing and widening linkages between existing sectoral classification to climate change adaptation measures

2. Integrating climate change adaptation measures over whole project cycle

VI. Conclusion

\section{References}




\section{Abstract}

While many developing countries are facing the immediate needs of adapting changing climate, climate change adaptation is still smaller size at global level but it has high potential to maximize its positive impact by connecting diverse relevant sectors. Overall trend in Korea's aid as well as KOICA's support in terms of budgeting larger volume has been allocated to climate change adaptation than mitigation. It signifies KOICA has already entered into the initial stage of mainstreaming adaptation. Still its climate change strategy remains on introductory level. The strategy does not cover practical issues particularly relating to project designing. As found in the Section 3 and 4, Korea overall as well as KOICA has spent more budget on adaptation. It can be translated into high potential to advance mainstreaming climate change adaptation.

However, the level of addressing adaptation in project designing is not much advanced., KOICA's adaptation support is highly concentrated to a few of particular sectors. This would be a challenging factor to diversify KOICA's adaptation mainstreaming. To do this, it needs to analyze at first existing portfolio of climate change support and focus on the sectors which are not yet connected with adaptation. KOICA then needs to explore sectoral adaptation measures. Such measures are already available and introduced in policy dialogue as well as at practical level particularly by other donor agencies as well as UNFCCC and IPCC. By referring to practices of other adaptation oriented DAC members having balanced portfolio, KOICA is expected to learn how to advance its adaptation approach in their project designing.

Key words : Climate change, Climate adaptation 


\section{Abbreviations and Acronyms}

COP7 Conference of the Parties

DAC Development Assistance Committee

Danida Danish International Development Agency

EACP East Asia Climate Partnership

EIA Environmental Impact Assessment

GIZ German Society for International Cooperation

IIED International Institute for Environment and Development

KOICA Korea International Cooperation Agency

Norad Norwegian Agency for Development Cooperation

ODA Official Development Assistance

OECD Organization for Economic Cooperation and Development

PPCs Priority Partnership Countries

SDGs Sustainable Development Goals

Sida Swedish International Development Cooperation Agency

UNFCC United Nations Framework Convention on Climate Change

USAID United States Agency for International Development

UN United Nations 


\section{Introduction}

\section{Research background}

\section{1) Development to sustainable development}

Development objectives and its concept have changed over the decades, recognizing that conventional development patterns which put greater emphasis on economic growth are flawed. Despite the efforts to achieve economic development, largely financed by foreign aid, many developing countries are still suffering from growing poverty and hunger, rising unemployment, international monetary disorder; chronic balance of payments deficits and mounting debts; and protectionism and tensions between countries competing for energy, food and raw materials. These complex development challenges hamper efforts to achieve development goals. Sustainability is today inevitably considered together with development. The concept of sustainable development initially focused on environmental aspects. The discourse of sustainable development has been, however, broadened to cope with multifaceted economic, social and environment dimensions in an inclusive manner. Sustainable development has become a key concept in the discourse on development policies.

\section{2) Sustainable development and climate change}

The North - South world is, meanwhile, now facing another challenge at the global scale, which is climate change. Changing climate affects all human activities, thereby impacting sustainable development. Climate change has historically existed; it is not wholly new challenge. However, the impact of the global climate change is rapidly and unexpectedly aggravating in more negative senses. Climate change impacts are expected to significantly affect sustainable development particularly among poorer countries which generally appear to have more vulnerable conditions to climate change. A variety of dimensions ranging from economic to social and environmental matters within climate change are widely intertwined with the considerations of sustainable development. For instance, developing countries facing with the problem of sea-level rise due to changing climate appear to be more 
vulnerable, compared to advanced countries in terms of economic, social and environmental resilience. Such conditions vulnerable countries encounter makes them less capable to carry on their development in a sustainable way.

Climate change is the result of increasing greenhouse gas emission caused by the conventional development patterns that can be characterized by the emphasis on economic growth, technology advance and use of natural resources. Conversely, impacts of climate change have reached an intolerable level, aggravating vulnerability as well as threatening sustainable development objectives of the world. Indeed, socio-economic development is obviously interconnected with the impact and vulnerability of climate change and the human capacity for mitigation and adaptation. The impacts of climate change on human and natural systems in turn influence socio-economic development patterns and thereby greenhouse gas emissions ( $<$ Figure $1>$ ). In addition, both climate change and sustainable development are overlapped with a number of cross-cutting sectors, such as agriculture, food crisis, migration, sanitation, transportation, urban planning, energy, and social and economic infrastructure. Therefore, the inter-linkage between climate change and sustainable development is evident. (Klein et al., 2005).

\section{〈Figure 1〉 Schematic framework of climate change, impacts and responses}

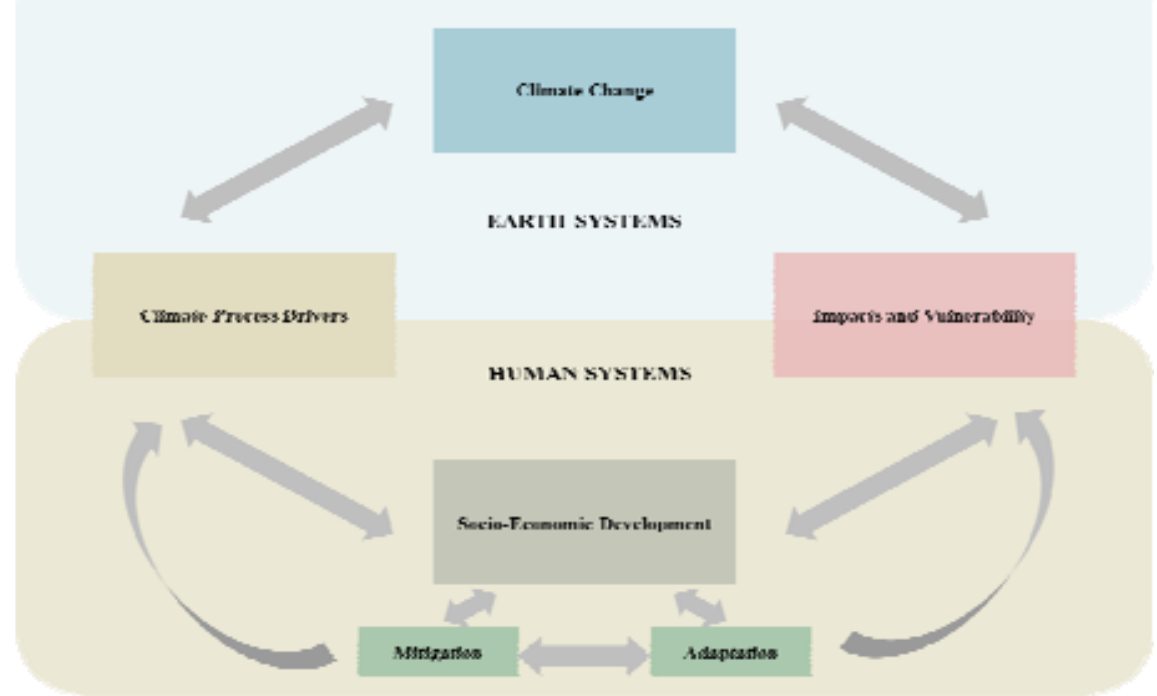

Source: IPCC website (https://www.ipcc.ch/publications_and_data/ar4/wg3/en/ch12-ens 12-2-4-6. html, 접속일: 2017.06.21.) 


\section{3) Sustainable development threatened by climate change}

Increasing vulnerability to climate change directly threatens sustainable development, aggravating the problems for which the South has struggled so far. The adverse impacts of climate change in developing countries would negatively influence developed countries as well since the scope of climate change-induced hazards is global rather than local or regional. Thus, the international development community needs to respond to the global climate change so that both North and South ensure, and move forward towards, sustainable development.

Development pathways, particularly in the world's poorest countries, can either increase or diminish the impacts and vulnerability of households and communities to climate change. Development activities therefore need to be included in the climate change policy area when assessing the vulnerability to climate change of the world's poor. For instance, diversification of livelihood sources, improved and greener infrastructure, education and institutional strength all help to reduce vulnerability to climate change as well as encouraging economic, social and environmental development, that is, sustainable development. In this respect, particularly, climate change adaptation and sustainable development share many of the goals to reduce vulnerability.

However, issues of justice are brought up with regard to recognizing dilemmas of adaptation for developing nations (Adger et al., 2003; Paavola and Adger, 2006). Climate change is largely caused by greenhouse gas emissions of developed countries, whereas the impacts of climate change burdens disproportionately developing countries. At the seventh Conference of the Parties (COP7) held in Morocco, 2001, delegates paid attention to both adaptation to climate change and mitigations measures, formally recognizing the dilemmas of adaptation for the developing nations (Ibid.). The Intergovernmental Panel on Climate Change (hereinafter "IPCC")'s third assessment report also highlights that the impacts of climate change are not evenly distributed; the people who will be exposed to the worst of the impacts are the ones least able to cope with the associated risks (IPCC, 2001). That is, despite climate change occurring at the global level, vulnerability 
and sensitivity to the risks posed by climate change are different at smaller level, depending on geographic, economic and social dimensions. In addition, many of the dilemmas are acute among the poorest and most vulnerable groups and in developing countries of which the dependency of natural resources is high (Thomas and Twyman, 2005).

제 I 장

Climate change is intrinsically linked to sustainable development (OECD, 2009a). However, until recently, climate change was viewed largely as an environmental concern, and development policy-makers and practitioners have paid less attention to climate change. Likewise, development approaches have been given less attention within the climate change community. Climate change can no longer overlook the fact that the negative impact of the global climate change would make the South more vulnerable as well as hinder both South and North from achieving the objectives of sustainable development. Furthermore, without addressing climate change issues, development policies and practices would be obsolete (Huq et al., 2006). Coping with climate change is, thus, a new pathway of sustainable development.

\section{5) Research purpose}

Climate change has become one of the major issues in development cooperation. However, the concept of climate change adaptation has been often undermined in Korea's development project designing. In Korea, awareness of climate change, both mitigation and adaptation, is very low; it is generally understood as a part of environment protection. Facing this condition, this research, as a preliminary research, aims at analyzing current status of climate change adaptation and provide implications for developing further toolkits and guidelines for Korea International Cooperation Agency (hereinafter "KOICA"). 


\section{Analytical framework}

\section{Conceptual setting}

\section{1) Climate change beyond environmental concerns}

Climate change is interconnected with various dimensions ranging from social inequalities, economic costs and environmental degradation. However, given that climate change is often confined to environmental concerns, the adverse impact of climate change is regarded as natural hazards. This research fundamentally takes broader view of climate change beyond environmental perspectives. Füssel's analysis is referred in order to clarify the distinction between climate change and natural hazard (<Table $1>$ ). Natural hazards, resulted from natural processes of the Earth, are sudden-onset events such as landslide, earthquake, avalanche, and floods, affecting a relatively small area.

$\langle$ Table 1〉 Characteristics of natural hazards and climate change

\begin{tabular}{l|l|l}
\hline & Natural hazards & Climate change \\
\hline $\begin{array}{l}\text { Hazard characteristics: } \\
\text { - Temporal }\end{array}$ & Discrete events & $\begin{array}{l}\text { Long-term and continuous } \\
\text { - Spatial scope }\end{array}$ \\
$\begin{array}{l}\text { - Uncertainty } \\
\text { - Attribution }\end{array}$ & $\begin{array}{l}\text { Regional } \\
\text { Low to medium } \\
\text { Natural variability }\end{array}$ & $\begin{array}{l}\text { Nedium to very high } \\
\text { Natural and anthropogenic }\end{array}$ \\
\hline Systems of concern & $\begin{array}{l}\text { Social systems and built } \\
\text { infrastructure }\end{array}$ & All systems \\
\hline Consequences & Specific impacts & Broad range of impacts \\
\hline
\end{tabular}

Source: Füssel (2007)

On the other hand, climate change hazards are inherent in a particular environment but more likely to be attributed to man-made activities such as greenhouse gas emission. In this regard, climate change is a continuous process, and the scope affected by hazardous events of climate change is likely to be transboundary and vary or depending on climate events. Moreover, the uncertainty associated with 
climate change is higher than the one regarding natural hazards. As such, climate change has more multiple effects on societies and other vulnerable systems than natural hazards (Füssel, 2007).

제I장

2) Principal responses to climate change - mitigation and adaptation

Major response strategies to climate change are commonly understood as mitigation and adaptation (Huq and Reid, 2004). Mitigation means diverse ways of human intervention to reduce greenhouse gases. Examples are optimizing energy efficiency of industrial processes, electricity generation or buildings, promoting transition from the use of fossil fuel-based energy to renewable energy, and expanding certain processes, activities or mechanisms which remove a greenhouse gas etc (UNFCCC, 2016). Adaptation has broader definition compared to mitigation. Adaptation refers to adjustments in ecological, social or economic systems in response to actual or expected climatic stimuli and their effects or impacts. It includes changes in processes, practices, and structures to moderate potential damages or to benefit from opportunities associated climate change1).

\section{3) Definition of climate change mainstreaming}

Mainstreaming is not a unique terminology for climate change. It can be understood as a concept that makes peripheral issues being at the centre of discussions in order to heighten political attention and will, and attract more financial and human resources (Van der Grijp, N, 2010). In policy studies, mainstreaming has been widely applied. Particularly, development issues such as gender equality, environmental degradation and HIV/AIDS have been the subjects of mainstreaming (ODI, 2011). Likewise, the concept of mainstreaming has been used in the discourse of climate change. Organization for Economic Cooperation and Development (hereinafter "OECD") found early discussions under the United Nations Framework Convention on Climate Change (hereinafter "UNFCCC") framework emphasized more on mitigation than adaptation (Jennifer Helgeson, 2015). It is evaluated the UNFCCC-led discourses regarded adaptation as the second best response to a

1) source: UNFCCC. "FOCUS : Adaptation" posted on UNFCCC official website, available at http://unfccc.int/ focus/adaptation/items/6999.php. (접속일: 2017.06.21.) 
mitigation option (E. Lisa et al., 2007). IPCC, a leading international experts group of climate change assessment, also mentioned in its report published in 2007 mainstreaming means development policies and programmes that otherwise would not have taken climate change mitigation into consideration explicitly include these when making development choices (IPCC, 2007). Meanwhile, adaptation to climate change has become recently the main focus of mainstreaming in the context of climate change.

\section{4) Why adaptation rather than mitigation matters for developing countries}

Reducing green house gases is universal goal to achieve for the world, both developed and developing countries. However, the goal is more oriented to developed countries. Brundtland Report also articulated this argument by introducing a normative principle named 'common but differentiated responsibilities'. It acknowledges that developed countries are the main contributor to human-induced climate change because resource exploitation and energy-intensive industries had been easily allowed, and even encouraged, for economic growth under conventional development patterns primarily led by the North (Baker 2006, 35-7).

Adapting to climate change also has become serious concern both for the North and South. Development and environment ministers of OECD member countries recognized in 2006 when the concept of sustainable development was not yet at the center of discussion among Development Assistance Committee (hereinafter "DAC") donors the significance of integrating climate change adaptation into development cooperation. OECD particularly concerns the vulnerability to adverse effects of climate change of least developed countries. In this respect, the Declaration on Integrating Climate Change Adaptation into Development Cooperation of OECD indicates that responses to climate change should be coordinated with social and economic development in an integrated manner by taking into account the legitimate priority needs of developing countries for the achievement of sustainable economic growth and the eradication of poverty.

However, developing countries are more likely to prone to adverse impacts of 
climate change. Some scholars summarize determinants on why the adverse impacts of climate change are more severe in developing countries (Ole Mertz et al., 2009). First, the impacts are relatively large in developing countries due to the fact that many developing nations are located in low-latitude regions. In such low-latitude countries, in general, increase in temperature is found already high and this is more likely to bring large scale evaporation losses resulting in more dynamic changes in climate condition. Second, a large number of populations in developing countries are highly dependent in terms of economic activities on agriculture which is directly affected by climate change. In this respect, it is very evident that climate change is crucial for developing countries in the course of realizing sustainable development. However, many developing countries have been struggling with a lack of capacity, economic as well as technical, in terms of coping with climate change adaptation. Scholars and professionals in development and climate change scene describe such limited capacity to adapt climatic change as 'adaptation deficit.'

Moreover, looking into development problems in developing countries, challenges are heavily rely on climate-vulnerable sectors such as agriculture, water resources, forests and biodiversity to maintain and improve the living conditions of their populations. Adaptation approaches can be taken in diverse ways including vulnerability reduction, disaster risk management, or proactive adaptation planning as solutions for the development problems observed in societies of developing countries (IPCC, 2016). It is therefore important to manage climate change adaptation as part of our development approach. Such an integrated approach will make development more resilient by reducing climate impacts and identifying development opportunities that may otherwise be overlooked. However, awareness of the significance of climate change adaptation has still not embedded in the work of development agencies (Burton, I., 2004). That is the reason why this study mainly looks into the current status of climate change adaptation among donor agencies.

Policy-makers and implementation entities in development cooperation also recognize the high relevance and significance between climate change adaptation and sustainable development. The German Society for International Cooperation (hereinafter "GIZ"), the German federally owned international cooperation enterprise, 
points out climate change adaptation is highly relevant to official development assistance (hereinafter "ODA"). GIZ considers climate change adaptation as a long-term sustainability component to development cooperation with the following three aspects. First, risk of climate change would directly and indirectly affect to ODA projects in a negative way, aggravating as well as cost effectiveness and sustainability of the results and impact of projects. Conversely, second, ODA projects would negatively intensify vulnerability to climate change by maladapting measures of development assistance without considering climate change adaptation. Third, beneficiaries of ODA projects are already and inevitably confronting adverse effects of climate change which result in making them adopting changing environment such as increase of heavy rain, sea-level rise, desertification, and increase in temperature, with regard of their livelihood in community as well as ecosystem. In this regard, GIZ emphasizes risk assessment, vulnerability assessment and environmental impact assessment as viable and basic level of options for incorporating climate change adaptation into ODA projects (GTZ, 2001). OECD also explicitly recognizes close linkage between climate change adaptation and sustainable development. It recommends integration of adaptation into all phases of ODA policy-making and project planning in its report published in 2006 titled as Declaration on Integrating Climate Change Adaptation into Development Cooperation.

\section{Methodology}

According to OECD, budget shows how certain topic or issue is prioritized thereby influencing, and building up, specific environment and achieving expected objectives (OECD, 2014). Referring to this feature of budget, this research uses the data of ODA budget amount to see the status and trend of climate-related ODA support from the 28 DAC donors to partner countries. This research looks into the ODA amount of 28 DAC member countries - Australia, Austria, Belgium, Canada, Czech Republic, Denmark, Finland, France, Germany, Greece, Iceland, Ireland, Italy, Japan, Korea, Luxembourg, the Netherlands, New Zealand, Norway, Poland, Portugal, Slovak Republic, Slovenia, Spain, Sweden, Switzerland, United Kingdom and United States. The European Union (EU) is a DAC member but this research excludes 
the EU to prevent upward-leveling due to its relatively large size of ODA.

All 28 DAC members are Parties of the UNFCCC. Given that the 28 countries undertake responsibility to contribute to development and climate change, they are used as a representative sample in this research to see the trend of climate change-related support within their ODA budget. As for the objective of this research, it is to find out implications for KOICA on advancing its strategic approach of mainstreaming climate change adaptation. Data on the ODA amount of the 28 countries includes the budget of each DAC member's aid-related agencies and ministries. In this aspect, the components of the data have similarity with KOICA which is a grant implementation agency of the Korean government.

Three categories of the ODA statistics are the main data of this research. One is the total ODA based on current prices. The others are the ODA amount marked with two Rio Markers - climate change mitigation and adaptation. The research counts the Rio Markers with the labeling of both principal and significant as climate change purpose ODA. Moreover, the research tracks the data during the recent five years from 2010 to 2014. It is because the Rio Marker of climate change adaptation has been collected since 2010. Then, the research examines distribution of the climate change purpose ODA by sectors. Regarding climate change adaptation is multiply connected with more than one sector, the research considers more the climate change purpose ODA is harmoniously distributed, more climate change adaptation is mainstreamed (Asa Persson, 2008). Referring to the ODA statistics, this research could show where the ODA of Korea is placed compared to other donors.

The research also tracks the pathway that KOICA has built up strategies regarding climate change overall as well as climate change adaptation-oriented. Moreover, KOICA's activities in climate change are also studied at project-level. In addition to KOICA, efforts in incorporating climate change adaptation of other donors and institutions are to be looked into. From the works done by other donors, it is expected to draw some implications for KOICA to further advance its measure in climate change adaptation. 


\section{Recent trend of climate adaptation mainstreaming among global donors}

\section{Mitigation relatively mainstreamed in terms of ODA volume}

In the context of implementing sustainable development, DAC 28 countries have spent a diverse proportion of their ODA to climate change mitigation and adaptation. As a result of analyzing the trends of climate change related support from the DAC between 2010 and 2014, USD 121,932, equivalent to 22\% of their total ODA (USD $563,359)$, was allocated for climate change purpose 2 . The following detailed data shows climate change mitigation is, in the ODA portfolio of the DAC, relatively prioritized than climate change adaptation. Climate change mitigation amounts to USD 76,677, 63\% of the total climate change purpose ODA, while the remaining $37 \%$ (USD 45,255) is oriented to climate change adaptation (<Table $2>$ ).

〈Table 2〉 Climate change purpose ODA amount of DAC donors (USD million, 2010-2014)

\begin{tabular}{|c|c|c|c|c|c|c}
\hline & DAC Donors & $\begin{array}{c}\text { Climate } \\
\text { change } \\
\text { adaptation } \\
(\mathrm{A})\end{array}$ & $\begin{array}{c}\text { Climate } \\
\text { change } \\
\text { mitigation } \\
\text { (B) }\end{array}$ & $\begin{array}{c}\text { Climate } \\
\text { change } \\
\text { purpose } \\
\text { (C=A+B) }\end{array}$ & $\begin{array}{c}\% \text { of } \\
\text { adap- } \\
\text { tation }\end{array}$ & $\begin{array}{c}\% \text { of } \\
\text { mitiga- } \\
\text { tion }\end{array}$ \\
\hline 1 & TOTAL & $45,254.61$ & $76,677.20$ & $121,931.81$ & $37 \%$ & $63 \%$ \\
\hline 2 & Japan & $11,195.00$ & $24,044.82$ & $35,239.82$ & $32 \%$ & $68 \%$ \\
\hline 3 & Germany & $8,963.44$ & $17,270.38$ & $26,233.82$ & $34 \%$ & $66 \%$ \\
\hline 4 & France & $2,942.20$ & $11,874.30$ & $14,816.49$ & $20 \%$ & $80 \%$ \\
\hline 5 & United States & $2,962.27$ & $4,639.01$ & $7,601.28$ & $39 \%$ & $61 \%$ \\
\hline 6 & Norway & $1,369.28$ & $3,970.43$ & $5,339.71$ & $26 \%$ & $74 \%$ \\
\hline 7 & United Kingdom & $2,216.62$ & $2,812.30$ & $5,028.92$ & $44 \%$ & $56 \%$ \\
\hline 8 & Sweden & $2,652.45$ & $2,318.00$ & $4,970.45$ & $53 \%$ & $47 \%$ \\
\hline & Australia & $1,893.57$ & $1,645.79$ & $3,539.36$ & $54 \%$ & $46 \%$ \\
\hline
\end{tabular}

2) Climate change purpose is defined as a support reported to Rio Marker under the categories of climate change mitigation and climate change adaptation. In this research, two scores which are principal and significant are categorized as climate change purpose. 


\begin{tabular}{|c|c|c|c|c|c|c|}
\hline \multicolumn{2}{|r|}{ DAC Donors } & \multirow{2}{*}{$\begin{array}{c}\text { Climate } \\
\text { change } \\
\text { adaptation } \\
\text { (A) } \\
1,603.06\end{array}$} & \multirow{2}{*}{$\begin{array}{c}\text { Climate } \\
\text { change } \\
\text { mitigation } \\
\text { (B) } \\
1,718.89\end{array}$} & \multirow{2}{*}{$\begin{array}{c}\text { Climate } \\
\text { change } \\
\text { purpose } \\
(\mathrm{C}=\mathrm{A}+\mathrm{B}) \\
3,321.95\end{array}$} & \multirow{2}{*}{ 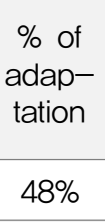 } & \multirow{2}{*}{$\begin{array}{c}\% \text { of } \\
\text { mitiga- } \\
\text { tion }\end{array}$} \\
\hline 9 & Denmark & & & & & \\
\hline 10 & Netherlands & 2,213.26 & 847.01 & $3,060.27$ & $72 \%$ & $28 \%$ \\
\hline 11 & Switzerland & $1,485.97$ & $1,027.80$ & $2,513.78$ & $59 \%$ & $41 \%$ \\
\hline 12 & Canada & $1,047.51$ & $1,128.95$ & $2,176.46$ & $48 \%$ & $52 \%$ \\
\hline 13 & Spain & $1,550.89$ & 719.13 & $2,270.02$ & $68 \%$ & $32 \%$ \\
\hline 14 & Belgium & 788.74 & 696.75 & $1,485.49$ & $53 \%$ & $47 \%$ \\
\hline 15 & Finland & 705.51 & 596.50 & $1,302.01$ & $54 \%$ & $46 \%$ \\
\hline 16 & Korea & 726.64 & 284.66 & $1,011.30$ & $72 \%$ & $28 \%$ \\
\hline 17 & Italy & 215.43 & 370.86 & 586.29 & $37 \%$ & $63 \%$ \\
\hline 18 & Ireland & 299.69 & 157.38 & 457.07 & $66 \%$ & $34 \%$ \\
\hline 19 & Austria & 112.86 & 187.29 & 300.15 & $38 \%$ & $62 \%$ \\
\hline 20 & New Zealand & 133.80 & 119.72 & 253.52 & $53 \%$ & $47 \%$ \\
\hline 21 & Portugal & 8.33 & 129.66 & 138.00 & $6 \%$ & $94 \%$ \\
\hline 22 & Luxembourg & 108.68 & 73.53 & 182.21 & $60 \%$ & $40 \%$ \\
\hline 23 & Iceland & 25.68 & 15.42 & 41.10 & $62 \%$ & $38 \%$ \\
\hline 24 & Poland & 10.32 & 9.96 & 20.28 & $51 \%$ & $49 \%$ \\
\hline 25 & Czech Republic & 11.99 & 5.90 & 17.89 & $67 \%$ & $33 \%$ \\
\hline 26 & Slovenia & 5.50 & 7.58 & 13.07 & $42 \%$ & $58 \%$ \\
\hline 27 & Greece & 5.59 & 4.46 & 10.05 & $56 \%$ & $44 \%$ \\
\hline 28 & Slovak Republic & 0.34 & 0.69 & 1.03 & $33 \%$ & $67 \%$ \\
\hline & TOTAL & $45,254.61$ & $76,677.20$ & $121,931.81$ & $37 \%$ & $63 \%$ \\
\hline
\end{tabular}

제 I 장

제II장

제피장

This research classifies 28 DAC members into two groups - mitigation- and adaptation-oriented $(<$ Table $3>,<$ Table $4>$ ). This research defines mitigation- or adaptation oriented if the proportion of mitigation or adaptation among climate change purpose is more than 50\%. As a result, 15 countries are adaptation oriented and 13 are mitigation oriented. Mitigation oriented ODA amount (USD 447,558) is 3 times bigger than adaptation oriented ODA amount (USD 115,801). Average amount of mitigation oriented group is USD 29,837 while average of adaptation 
oriented group is USD 4,135. The mitigation oriented group has smaller number of countries and larger volume. It shows more ODA is concentrated in climate change mitigation.

There is also a tendency that larger donors in terms of ODA volume focus on climate change mitigation while smaller donors concentrate on climate change adaptation. 8 countries - Japan, Germany, France, United States, Norway, United Kingdom, and Canada - of top 10 DAC donors in terms of ODA volume during the recent 5 years are found in the list of climate change mitigation oriented countries $(<$ Table $3>$ ). The list of climate change adaptation oriented countries is composed of 15 DAC donors (<Table $3>$ ). 80\% (12 countries) of them drop out the top 10 DAC members ( $<$ Table $4>$ ).

〈Table 3〉 Mitigation oriented DAC members (2010-2014)

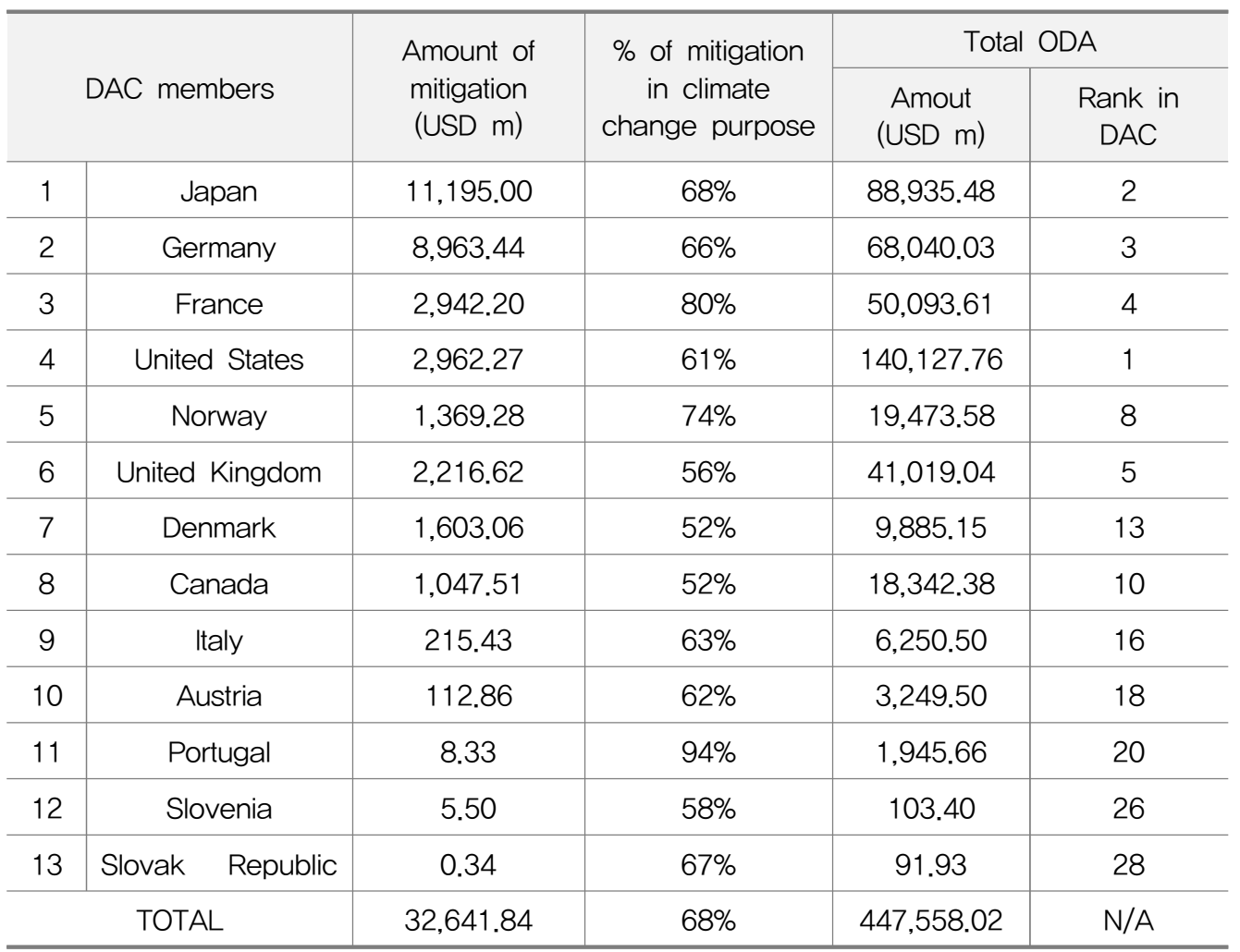


〈Table 4〉 Adaptation oriented DAC members (2010-2014)

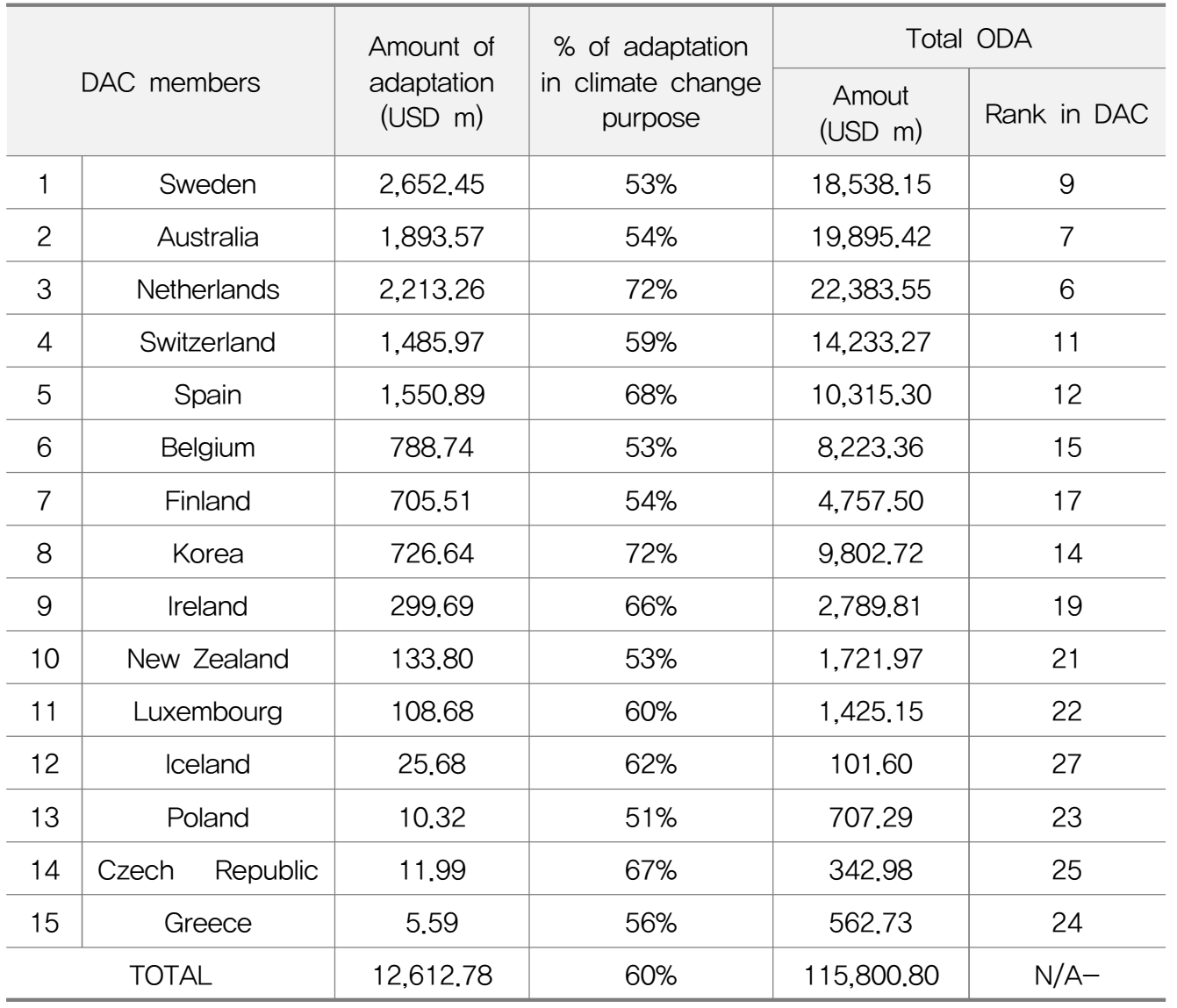

제 I 장

By breaking down the level of mitigation and adaptation mainstreaming in terms of ODA volume, the tendency becomes clearer. The research sets the levels of mitigation and adaptation mainstreaming, ranging from 0 to 5 ( $<$ Table $5>$, $<$ Table $6>,<$ Table $7>$ ). 0 is the lowest level of mainstreaming and 5 is considered a fully mainstreamed status. 10 of the 13 mitigation oriented countries are distributed between the level 1 and 2. 3 mitigation oriented countries are found at the level 3 (Norway), 4 (France), and 5 (Portugal) respectively. All 15 adaptation oriented countries are dispersed over the range from 1 to 3 . Particularly 9 of them are presented at the level 1 . This shows mainstreaming of climate change mitigation is relatively more progressed. 
〈Table 5〉 Level of climate change mainstreaming of DAC members (2010-2014)

\begin{tabular}{|c|c|c|c|c|c|}
\hline $\begin{array}{l}\text { Mitigation } \\
\text { oriented } \\
\text { countries }\end{array}$ & $\begin{array}{c}\% \text { of } \\
\text { mitigation } \\
\text { in climate } \\
\text { change } \\
\text { purpose }\end{array}$ & $\begin{array}{c}\text { Level of } \\
\text { mitigation } \\
\text { mainstreaming* }\end{array}$ & $\begin{array}{c}\text { Adaptation } \\
\text { oriented } \\
\text { countries }\end{array}$ & $\begin{array}{l}\% \text { of } \\
\text { adaptation } \\
\text { in climate } \\
\text { change } \\
\text { purpose }\end{array}$ & $\begin{array}{c}\text { Level of } \\
\text { adaptation } \\
\text { mainstreaming* }\end{array}$ \\
\hline Japan & $68 \%$ & 2 & Sweden & $53 \%$ & 1 \\
\hline Germany & $66 \%$ & 2 & Australia & $54 \%$ & 1 \\
\hline France & $80 \%$ & 4 & Netherlands & $72 \%$ & 3 \\
\hline United States & $61 \%$ & 2 & Switzerland & $59 \%$ & 1 \\
\hline Norway & $74 \%$ & 3 & Spain & $68 \%$ & 2 \\
\hline $\begin{array}{l}\text { United } \\
\text { Kingdom }\end{array}$ & $56 \%$ & 1 & Belgium & $53 \%$ & 1 \\
\hline Denmark & $52 \%$ & 1 & Finland & $54 \%$ & 1 \\
\hline Canada & $52 \%$ & 1 & Korea & $72 \%$ & 3 \\
\hline Italy & $63 \%$ & 2 & Ireland & $66 \%$ & 2 \\
\hline Austria & $62 \%$ & 2 & New Zealand & $53 \%$ & 1 \\
\hline Portugal & $94 \%$ & 5 & Luxembourg & $60 \%$ & 1 \\
\hline Slovenia & $58 \%$ & 1 & Iceland & $62 \%$ & 2 \\
\hline \multirow[t]{3}{*}{$\begin{array}{c}\text { Slovak } \\
\text { Republic }\end{array}$} & $67 \%$ & 2 & Poland & $51 \%$ & 1 \\
\hline & & & $\begin{array}{c}\text { Czech } \\
\text { Republic }\end{array}$ & $67 \%$ & 2 \\
\hline & & & Greece & $56 \%$ & 1 \\
\hline
\end{tabular}


〈Table 6〉 Detailed level of climate change mainstreaming of DAC members (2010-2014)

\begin{tabular}{c|c|c|c|c|c|c|c}
\hline \multirow{2}{*}{$\begin{array}{c}\text { Level of } \\
\text { mainstreaming* }\end{array}$} & Not & \multicolumn{2}{|c|}{ Moderately } & & Fully & Total \\
\cline { 2 - 7 } & 0 & 1 & 2 & 3 & 4 & 5 & 13 \\
\hline $\begin{array}{c}\text { Mitigation oriented } \\
\text { countries }\end{array}$ & 0 & 4 & 6 & 1 & 1 & 1 & 15 \\
\hline $\begin{array}{c}\text { Adaptation oriented } \\
\text { countries }\end{array}$ & 0 & 9 & 4 & 2 & 0 & 0 & 15 \\
\hline Total & 0 & 13 & 10 & 3 & 1 & 1 & 25 \\
\hline
\end{tabular}
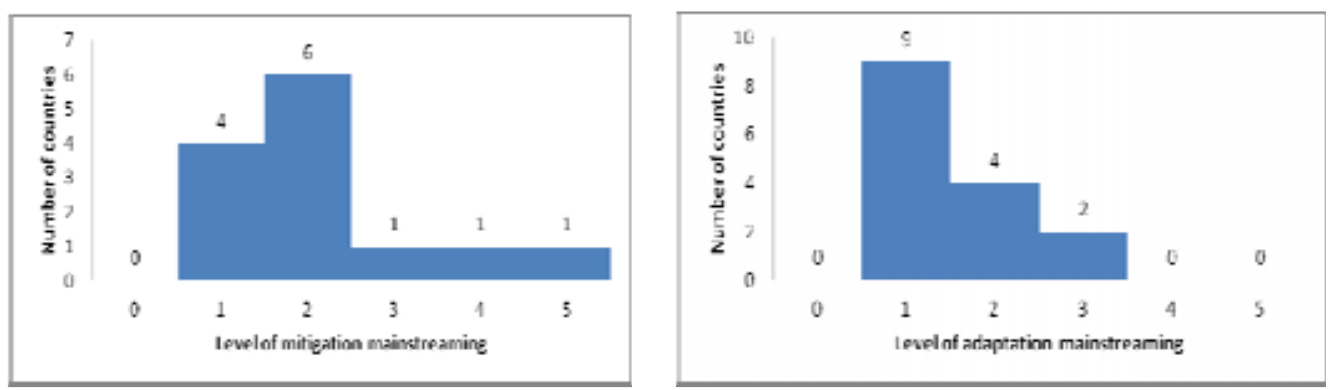

* 0: less than $50 \%, 1$ : more than $50 \%$ and less than $60 \%, 2$ : more than $60 \%$ and less than $70 \%$,

3: more than $70 \%$ and less than $80 \%$, 4 : more than $90 \%$ and less than $100 \%$

\section{Unbalanced portfolio of climate change adaptation}

As mentioned earlier, adaptation is linked and incorporated with diverse development sectors. Mainstreaming adaptation is more likely to make and deepen linkages with the fields that development community has long concerned, such as social (education, health, population policies, programmes and reproductive health, water supply and sanitation etc.) and economic (transport and storage, communications, energy etc.) infrastructure and services, production sector (agriculture, forestry, fishing, industry, mining, construction, tourism etc.), multi- and cross-cutting sector (general environment protection etc.), and humanitarian assistance (emergency response, reconstruction relief and rehabilitation, disaster prevention and preparedness etc.). On the other hand, putting, and spending, more budget to adaptation does not fully mean mainstreaming of climate change adaptation. Advanced level of adaptation mainstreaming shows more connections with many sectors. 
〈Figure 2〉 Sectoral distribution of adaptation oriented countries
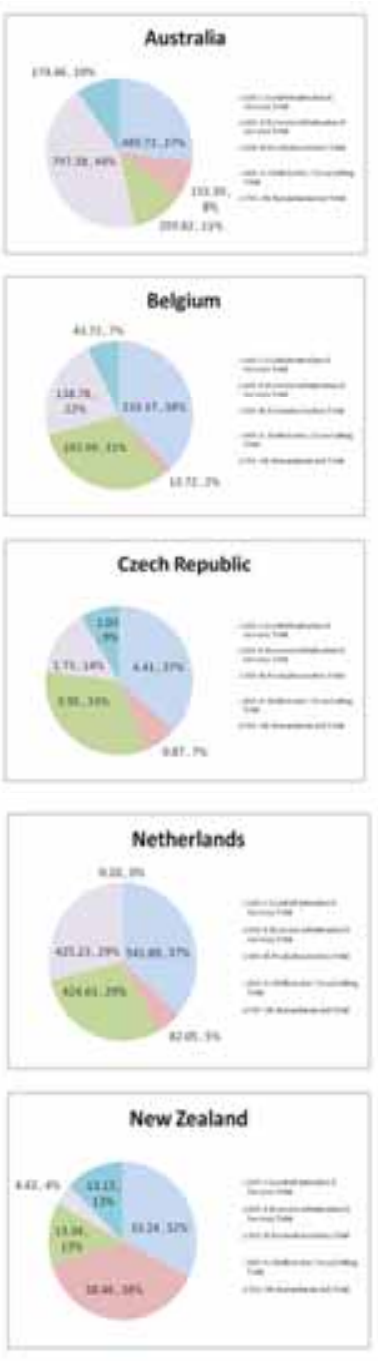
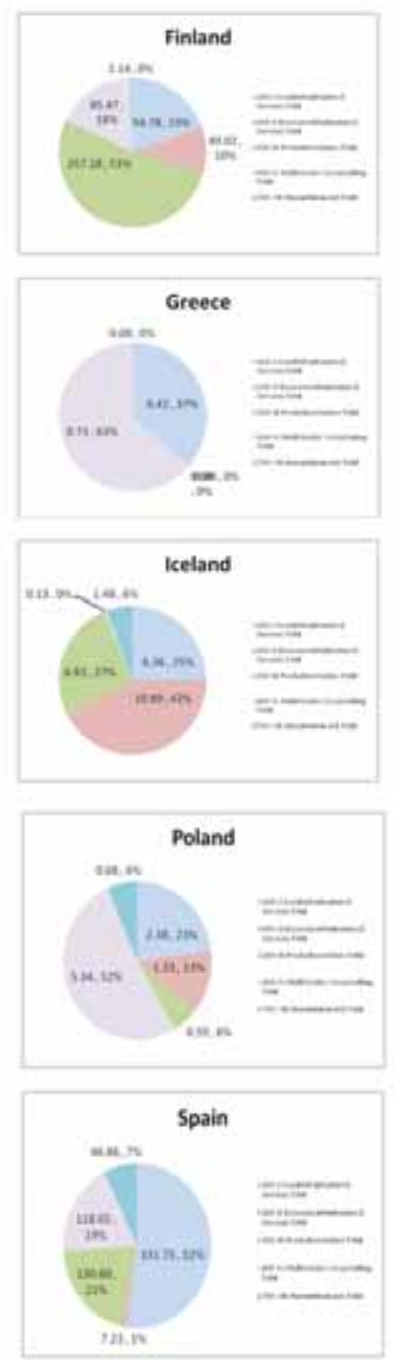
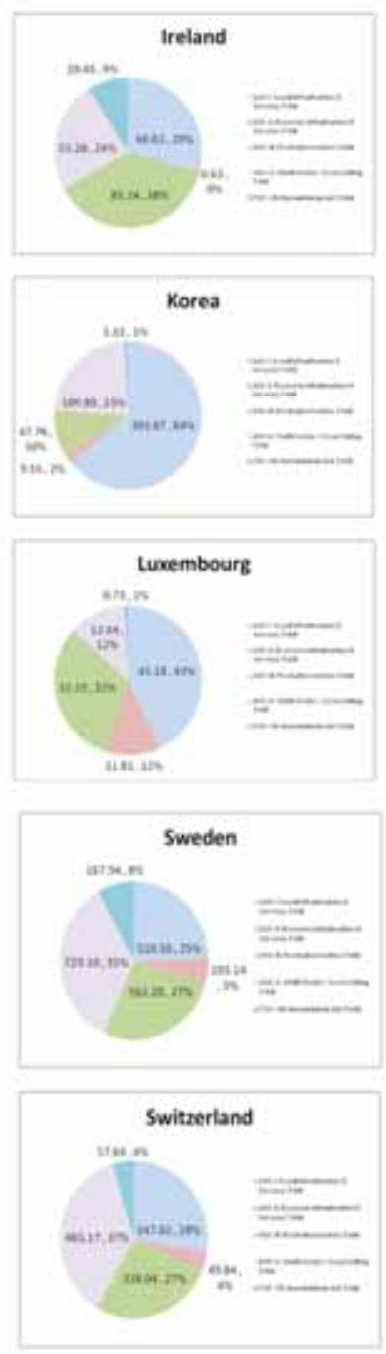

Referring to the $\langle$ Table 5$\rangle$, Netherlands and Korea seem to have high level of adaptation mainstreaming in terms of concentration ratio of ODA to adaptation. However, it is quite interesting that more balanced portfolio of spending to adaptation is observed from Netherlands $(<$ Figure $2>$ ). Its adaptation oriented ODA is evenly distributed to three sectors - social infrastructure and services, production sectors, and multi- and cross $^{-}$cutting sectors. Meanwhile, even though Korea is seen as an advanced DAC member in terms of its high ratio to adaptation, its adaptation portfolio is revealed as very narrowly focused. Most of Korea's adaptation oriented 
ODA has been spent to social infrastructure and services. Therefore, the level of adaptation mainstreaming is not simply explained only by large amount and high percentage of adaptation in climate change purpose. It is more associated with balanced use of climate finance to wider range of sectors.

제I장 


\section{Current status of climate change adaptation approach of KOICA}

\section{Strategic efforts in responding climate change}

KOICA actively expanded responses to climate change by applying domestic strategy of green growth and international dialogue of climate finance which was rapidly grown during the 2000s. According to the National Green Growth Strategy, the portion of green ODA is to be increased to 30\% of the total ODA by 2020. As a result, climate change purpose support was sharply grown by the end of 2000. In particular, East Asia Climate Partnership (hereinafter "EACP”) was launched in 2008 with a total budget of USD 200 million for the period 2008-2012. Its objective is to combat climate change and foster a climate change resilient paradigm for developing countries in Asia and the Pacific. EACP has five priority areas including water resources management, waste management, low-carbon energy, low-carbon city and forestation and biomass. It helps climate change support of KOICA grow in volume as well as diversify in its portfolio. In 2010, $10 \%$ of bilateral project budget of KOICA was allocated to climate change purpose support. In line with the EACP, KOICA has established its own mid-term climate change response strategy since 2000. Relevant strategies in other sectors including environment, water, and energy have been developed, relating to the climate change strategy. More specifically, Guideline on Environment Friendly Construction was also introduced and it concerns widely as well as deeply vulnerabilities cause by climate change thereby suggesting diverse ways of coping with climate change in construction.

The recent version of KOICA Climate Change Response Strategy 2016-2000 mainly focus on (a) support for climate change response project, (b) climate-related capacity building support, and (c) vitalization of financial mechanism. In addition to these pillars, the strategy plans to establish Climate Mainstreaming Tool as a next step to develop. The Strategy presents its sub-programs in each focus area. Under the support for climate change response project, three sub-programs are 
presented - (a1) mitigation and adaptation project, (a2) mainstreaming climate change, and (a3) application of innovative climate response technology. Climaterelated capacity building support suggests (b1) readiness and (b2) national greenhouse gas inventory establishment as its sub-programs. As for vitalizing financial mechanism, the strategy suggests (c1) linking with global development finance to climate change support, and (c2) partnering and $\mathrm{co}^{- \text {financing are }}$ suggested.

The strategy does not differentiate the two principal responses to climate change. Mitigation and adaptation are all included as component of the sub-programs. Some sub-programs have room for subdividing them thereby making the strategy more systemic and practical for application. The strategy originally concerns about mitigation and adaptation project and already projects exist and a portfolio can be analyzed based on the existing ones. Thus, the sub-program (a1) can be set more ambitious. Setting this mid-term strategy is understood as a part of effort of mainstreaming climate change. In this regard, the sub-program (a2) might be improved in a more specific ways. The sub-program (a3) only considers innovative technology but a variety of technologies are available in respective industries which can be applicable specifically for mitigation or adaptation. Further process of developing this strategy might categorize available technologies into migration and adaptation and present them as secotral mitigation or adaptation measures. Current strategy only provides possible measures of project designing - bilateral project, public-private partnership, multilateral project, open competition etc. Prior to guiding the form of partnering, how to design project and connect relevant technology and knowhow from outside KOICA needs to be guided by the strategy to development practitioners. In this regard, sub-program (b1), (b2), (c1) and (c2) might be incorporated in the main focus (a) as an option for designing mitigation or adaptation project.

\section{Progress in climate change adaptation at project-level}

Looking into the composition of KOICA's climate change support, environment and energy related projects are the biggest part and forestation sector is the second. 
By 2010, it is shown projects of climate change mitigation were majority while climate change mitigation projects, for instance, river rehabilitation and water, have recently increased. From 2005 to 2015, climate change purpose support of KOICA amounts to USD 380 million - USD 290 million for adaptation and USD 180 million for mitigation. During the period of EACP, from 2008 to 2012, climate change related support by KOICA shows a significant increase in the number of project and budget. However, with the end of the EACP, between 2010 and 2011, a rapid decrease in climate change related support is found. It shows the initial vision the EACP made has no connectivity and alignment to further strategic approach of KOICA. KOICA's climate change support is significantly focused on Asia. 53\% of its climate change support went to Asian countries such as Philippines, Mongolia and Indonesia. Given they are all its Priority Partnership Countries (PPCs), KOICA aligns the focus of climate change support to its overall organizational strategy. However, these countries show relatively low level of vulnerability while countries in Latin America and Oceania are in general known as having higher vulnerability to climate change and lower adaptive capacity. 


\section{Implications on advancing climate change adaptation for KOICA : Lessons from Other Donors}

1. Strategically syncing and widening linkages between existing sectoral classification to climate change adaptation measures connected to specific technology in reducing energy use, greenhouse gas intensity, net emissions, decarbonizing energy supply, and enhancing carbon sinks (IPCC, 2016). Meanwhile, response options for adaptation are regarded as being applied to all sectors depending with diverse approaches on context. According to the IPCC, such sectors would range from freshwater resources, to terrestrial and freshwater ecosystems, to coastal systems and low-lying areas, to marine systems and oceans, to food production system and rural areas development, to urban areas and key economic sectors and services, and to human health, security and livelihoods (IPCC, 2016).

Looking into what KOICA has focused, its development cooperation projects are essentially classified into five sectors: education, health, rural development, industry and energy, and public administration. In addition to them, KOICA deals with cross-cutting issues which are climate change, gender, human rights and information and communication technology. In line with the launching of Sustainable Development Goals (SDGs) by the United Nations (UN) in 2015, KOICA introduced Better Life for All Initiative by expressing its focus areas based. The initiative is composed of five sub-initiatives - Better Life for Girls, Inclusive and Sustainable Rural Development, Safe Life for All from Infectious Disease, Climate Compatible Development and Science, Technology, and Innovation for Better Life. Looking into the Climate Compatible Development, it recognizes climate change is a fundamental threat to development and objective is to help building up climate-resilient life for 
all. Backed by the Climate Change Response Strategy of KOICA explained earlier, this climate change focused initiative entails four areas of concentration - low carbon growth and sustainable waste management which are mitigation measures and water and disaster management and climate-smart agriculture which are which are adaptation measures. Such adaptation measures are associated with what KOICA have focused in the field of adaptation. A working paper of KOICA shows its adaptation projects primarily have been focused on water followed by agriculture and general environment protection (KOICA, 2015).

However, adaptation measures of KOICA have much wider and specific potential to expand and deepen by strategically rethinking its adaptation focus areas. For instance, water and disaster management are relevant to more than one of five sectors into which KOICA basically categorizes. Water and disaster management could be incorporated into public administration of partner countries by helping them understand potential risks from climate change and take preventive institutional measures in establishing water and disaster-related management system which can be regional and/or national. On the other hand, a specific area relating to water and disaster management also could be tackled in designing urban planning and rural development. As such, the nexus among sectors and areas needs to be strategically viewed and analyzed in order to multiply incorporate adaptation measures into general sectoral framework.

Some donor agencies link climate change adaptation measures widely as well as specifically to diverse sectors. In case of Swedish International Development Cooperation Agency (hereinafter "Sida"), it developed a matrix making linkages between its overarching strategy and climate change at sectoral level, thereby formulating climate change related objectives in the Swedish cooperation strategy. Its basic categorization is divided into 10 sectors ranging from health to education, research, democracy, human rights and gender equality, conflict, peace and security, humanitarian aid, sustainable infrastructure and services, market development, environment, and agriculture and forestry. The matrix guides how each sector could be viewed through the lens of climate change. In addition, taking a stance that adaptation to climate change needs to be mainstreamed in development policy and 
practice, Irish Aid has worked on incorporating potential impacts of climate change on all key sectors into development activities at both project and strategic levels. In particular, Irish Aid regards adaptation is inevitable because the rise in temperature is and will be happening for some time due to the natural process of the earth even though mitigation efforts are significantly and immediately effective. Irish aid also takes into practical account that the actions taken by politicians, businesses and individuals in responding to changing climate need longer perspective even though climate experts stress the urgent action of reducing greenhouse gas emissions. As a result, Irish Aid considers adaptive responses can be technological, behavioral, managerial or policy-based no matter which sector certain development activities are involved, thereby implementing adaptation activities in line with partner country priorities and plans (Irish Aid, 2014).

\section{Integrating climate change adaptation measures over whole project cycle}

Project support is in general a major modality in development cooperation led by donor agencies. It means climate change adaptation measures need to be embedded as a part of project cycle starting from project identification to appraisal, to design, to implementation and to monitoring and evaluation. Prior to entering into project cycle, projects are conceptualized with a wide scope often linking to a sector. Particularly at designing stage, projects are placed in line with specific strategies and plans at the level of national/regional/local or ministerial/agency. Following such sectoral approach, projects go through the project cycle. Having internalized climate change adaptation into its project cycle, United States Agency for International Development (hereinafter "USAID") considers climate risks and opportunities at the strategy, project and/or activity level at the phase of project identification, thus strengthening sustainability and impact of its investments. In line with this, USAID obligates climate risk screening as part of the development of all new its strategies by using climate information to characterize current and future climate risks and opportunities early in the course of decision - making. The 
screening is to help USAID identify the level of climate risks. The risks are divided into two categories - low and moderate to high risk (USAID, 2015). OECD also points out potential climate risks and effects on vulnerability need to be assessed at the beginning of the project cycle. OECD also highlights in its policy guidance on integrating climate change adaptation into development cooperation the advantages of the climate risks screening. First, the screening enables to avoid excessively risky projects. Secondly, it helps build in appropriate climate risk management measures and financing for vulnerable project to be implemented. Third, it is useful to prioritize projects more likely to contribute to reduce climate vulnerability.

For the next step of the climate risk screening, in-depth climate risk assessment is applicable at the stage of project appraisal and detailed design. The climate risk assessment is to identify possible adaptation measures to directly address identified climate risks. The climate risk assessment has no typical format or approach. However, Environmental Impact Assessment (hereinafter "EIA") is normally carried out at the stage of project appraisal. In spite of the fact that the EIA is more likely to cover and check issues directly associated with the environment, the EIA helps view and analyze surrounding issues with the lens of climate change sensitivity. In this regard, the practices and tool undertaken by the EIA are considered relevant in the context of climate change adaptation. In order to prioritize and select suitable options among identified adaptation measures, USAID has designed and applied in practice the adaptation decision matrix. The matrix is composed of multiple criteria such as effectiveness, cost, technical feasibility and social and cultural feasibility, and speed of implementation. The analysis result based on the matrix helps all stakeholders of respective project make mutually agreed and feasible decision for project implementation. At the phase of project implementation, selected options are integrated into its detailed activities.

During the implementation, the most crucial thing is not to lose sight of adaptation. To do this, monitoring and evaluation is important. Monitoring and evaluation is a process of doing-by-learning. Thus, adaptation measures incorporated into project activities need to be regularly monitored over lifetime of the project since climate 
conditions are usually variable and tend to evolve. Thus adaptation interventions might be modified, depending on monitored environment. OECD suggests the following issues need to be verified through monitoring and evaluation process whether the identified adaptation options are put in place, what unexpected problems arise in the implementation process, whether the adaptation options had any adverse or positive impacts on other sectors or regions and whether costs of adaptation exceeded those anticipated (OECD, 2009b).

제I장

the end of- and ex-ante project could be undertaken with standardized tools. International Institute for Environment and Development (hereinafter "IIED") have developed indicators which can track and measures the impact of climate change adaptation in partnership with DFID, Sida, Irish Aid, Danish International Development Agency (Danida), and Norwegian Agency for Development Cooperation (Norad). Facing the intense interest among actors in development in the development of results and monitoring and evaluation framework particular for adaptation, IIED reviewed existing indicators which have been used in diverse sectors and reorganized them into two categories with a climate lens. The first group of indicators is about capacity of institutions, government and civil society to understand climate change and to integrate adaptation into decision making. These indicators are assessed in light of existence of adaptation - directly or indirectly - incorporated policy, institutional and other mechanisms. The second group of indicators is the extent to which climate adaptation positively contribute to development. They are evaluated by the use of regular development indicators applied to populations or areas prone to potential risk from climate change. 


\section{Conclusion}

While many developing countries are facing the immediate needs of adapting changing climate, climate change adaptation is still smaller size at global level but it has high potential to maximize its positive impact by connecting diverse relevant sectors. Overall trend in Korea's aid as well as KOICA's support in terms of budgeting larger volume has been allocated to climate change adaptation than mitigation. It signifies KOICA has already entered into the initial stage of mainstreaming adaptation. Still its climate change strategy remains on introductory level. The strategy does not cover practical issues particularly relating to project designing. As found in the Section3 and 4, Korea overall as well as KOICA has spent more budget on adaptation. It can be translated into high potential to advance mainstreaming climate change adaptation.

However, the level of addressing adaptation in project designing is not much advanced, KOICA's adaptation support is highly concentrated to a few of particular sectors. This would be a challenging factor to diversify KOICA's adaptation mainstreaming. To do this, it needs to analyze at first existing portfolio of climate change support and focus on the sectors which are not yet connected with adaptation. KOICA then needs to explore sectoral adaptation measures. Such measures are already available and introduced in policy dialogue as well as at practical level particularly by other donor agencies as well as UNFCCC and IPCC. By referring to practices of other adaptation oriented DAC members having balanced portfolio, KOICA is expected to learn how to advance its adaptation approach in their project designing. 


\section{〈참고 문헌〉}

Adger, W Neil, Huq, Saleemul, Brown, Katrina, Conway, Declan, and Mike Hulme. 2003. "Adaptation to climate change in the developing world." Progress in development studies vol.3(3):179-95.

Asa Persson. 2008. "Mainstreaming Climate Change Adaptation into Official Development Assistance: A Case of International Policy Integration." EPIGOV Papers no.36:3.

Burton, Ian. 2004. "Climate change and the adaptation deficit." Adaptation and Impacts Research Group, Meteorological Service of Canada, Environment Canada:3.

E. Lisa, F. Schipper. 2007. "Climate Change Adaptation and Development: Exploring the Linkages." Working Paper no.107. Norwich: Tyndall Centre for Climate Change Research:4.

Füssel, Hans-Martin. 2007. "Vulnerability: a generally applicable conceptual framework for climate change research.” Global Environmental Change no.17(2):155-67.

GTZ. 2001. "Measures to Implement the UNFCCC: Adaptation to Climate Change in German Official Development Assistance - An Inventory of Activities and Opportunities, with a Special Focus on Africa." Eschborn: GTZ:10, 35-6.

Huq, Saleemul and Hannah Reid. 2004. "Mainstreaming adaptation in development." IDS bulletin vol.35:15-21.

Huq, Saleemul, Reid, Hannah, and Laurel A Murray. 2006. "Climate change and development links." Gatekeeper series no.123. London: IIED.

Irish Aid. 2014. “Adapting to Climate Change." Limerick: Irish Aid, available at https://www.irishaid.ie/media/irishaid/allwebsitemedia/20newsandpublicati ons/publicationpdfsenglish/environmental-key-sheet-1-climate-change-ad aptation.pdf. (접속일: 2017.06.21.)

Helgeson, Jennifer and Jane Ellis. 2015. "The Role of the 2015 Agreement in Enhancing Adaptation to Climate change." Climate change Expert Group papers vol.24. Paris: OECD.

IPCC. 2017. “TOPIC 4 Adaptation and Mitigation.” Climate Change 2014 
Synthesis Report: Fifth Assessment Report. Geneva: IPCC, available at http://ar5-syr.ipcc.ch/topic_adaptation.php. (접속일: 2017.06.21.)

Klein, Richard JT., Schipper, E Lisa F., and Suraje Dessai. 2005. "Integrating mitigation and adaptation into climate and development policy: three research questions." Environmental Science \& Policy vol.8(6):579-88.

KOICA. 2015. "Better Life for All - Korea's New Road to Sustainable Development." Seongnam: Korea International Cooperation Agency (KOICA):6.

Mertz, Ole, Halsnaes, Kirsten, Olesen, Jorgen E., and Kjeld Rasmussen. 2009. “Adaptation to Climate Change in Developing Countries." Environmental management vol.43(3):743-4.

OECD. 2014. “ThePrinciplesofBudgetaryGovernance.”Paris:OECD:1 2009a. "Climate Change and Development: Key Principles to Inform Climate Change Financing." Paris: OECD, available at http://www.oecd.org/ env/cc/43423222.pdf. (접속일: 2017.06.21.)

. 2009b. "Integrating Climate Change Adaptation into Development Cooperation - Policy Guidance.” Paris: OECD:121

ODI. 2011. "Background Note - The 'mainstreaming' approach to climate change adaptation: insights from Ethiopia's water sector." London: Overseas Development Institute (ODI), available at https://www.odi.org/sites/odi.org. uk/files/odi-assets/publications-opinion-files/7056.pdf. (접속일: 2017.06.21.)

Paavola, Jouni, and W Neil Adger. 2006. "Fair adaptation to climate change." Ecological Economics vol.56(4):594-609.

Thomas, David SG, and Chasca Twyman. 2005. "Equity and justice in climate change adaptation amongst natural-resource-dependent societies.” Global Environmental Change no.15(2):115-24.

UNFCCC. 2016. "Glossary of climate change acronyms.” Bonn: United Nations Framework Convention on Climate Change (UNFCCC), available at http://unfccc.int/essential_background/glossary/items/3666.php\#M (접속일: 2017.06.21.)

USAID. 2015. "Climate Change in USAID Strategies: A Mandatory Reference for ADS Chapter 201." Washington D.C.: USAID.

Van der Grijp, Nicolien. 2010. Mainstreaming climate change in development 
cooperation: Theory, practice and implications for the European Union. Cambridge: Cambridge University Press:67.

IPCC. 2007. "Climate Change 2007: Working Group III: Mitigation of Climate change" posted on IPCC official website, available at https://www.ipcc.ch/ publications_and_data/ar4/wg3/en/ch12-ens 12-2-4-6.html.(접속일: 2017.06.21.)

UNFCCC. "FOCUS : Adaptation" posted on UNFCCC official website, available at http://unfccc.int/focus/adaptation/items/6999.php. (접속일: 2017.06.21.) 